\title{
SUSTAINABLE DEVELOPMENT GOALS AND SME DECISIONS: THE CZECH REPUBLIC VS. POLAND
}

\author{
Jarmila Šebestová \\ Silesian University in Opava, Czech Republic \\ Włodzimierz Sroka \\ WSB University, Dabrowa Górnicza, Poland \\ North West University, South Africa
}

\begin{abstract}
Small and medium-sized enterprises (SMEs) are a "major engine" of economic growth and socioeconomic development and the achievement of numerous sustainable development goals (SDG). They should make SDGs a prominent selling point to demonstrate why consumers should buy from them to reduce waste and enhance recycling. If a consumer sees an SME engaged in the SDGs (goals 8, 9, and 12), it will be motivated to offer further support. Given these facts, the paper compares the Czech and Polish approaches to the circular economy by means of quantitative evaluation based on primary research (Czechia, 210 respondents) and qualitative context comparison in Poland. The research has confirmed that there are differences in both countries in relation to sustainable development goals, with SME decisions in the Czech SME sector being at level 1.0 of business sustainability, and in Poland being below level 1. Additionally, Czech entrepreneurs have more knowledge of and practice in "green" methods than their Polish counterparts.
\end{abstract}

Keywords: circular economy, recycling, sustainable business, waste management

DOI: http://dx.doi.org/10.15549/jeecar.v7i1.418

\section{INTRODUCTION}

The highly dynamic and intense changes in the business ecosystem, as well as the need to obtain and maintain a competitive position, compel enterprises to adopt the most appropriate business strategies (Borocki et al., 2019). This outcome is the same for all companies, regardless of size, sector of activity, or location. Based on current external and internal factors, small and medium enterprises (SMEs) should, therefore, make decisions that allow them to succeed and maintain their market position. Changes in the global market, e.g., internationalization, networking, the open innovation model, mass customization, and fiscal policies, affect all countries (Androniceanu et al., 2019). One should remember that SMEs face a very competitive environment due to the globalization process and new technologies (Lendel \& Varmus, 2013; Moravcikova \& 
Kliestikova, 2017; Sroka \& Szanto, 2018), the growing role of CSR in operations (Sroka \& Vveinhardt, 2018; Groucutt et al., 2018), interfirm cooperation, as well as both bilateral and multilateral activity (e.g., Kozma, 2017; Sebestova et al., 2017).

Interest in SMEs as engines of employment and drivers of the economy has been developing worldwide since the early 1980s. According to EU guidelines, SMEs can be defined as firms with fewer than 250 employees and an annual turnover not exceeding 50 million euros and/or an annual balance sheet total not exceeding 43 million euros (European Commission, 2005). SMEs have been found to play significant roles in the national economy. They are presented in all sectors of the economy and especially in the area of services, catering, wholesale, retail trade, consumer goods, and food industries (Velinov \& Ponomarev, 2016). Indeed, the value of SMEs has grown steadily, and they are now considered the most important part of the global economy and a major engine of economic growth (Bădulescu, 2010; Karpak \& Topcu, 2010; Meyer \& De Jongh, 2018; Siekelova et al., 2019; Androniceanu, 2019). This is because small businesses are characterized by dynamism, innovation, and efficiency, and their small size allows for faster decision-making processes. No wonder that many of these firms look at internationalization and export opportunities as the best way to survive in the markets (Massaro et al. 2017).

There are a number of benefits that SMEs bring to any economy, e.g., contribution to the economy in terms of output of goods and services; the creation of jobs at relatively low cost of capital (for example, according to Olah et al. (2019), SMEs provide work to $66.4 \%$ of all employees in the Czech Republic and $68.1 \%$ of the entire work force in Poland); being a vehicle for reducing income disparities; and improving linkages between economically, socially and geographically diverse sectors of the economy. In other words, one may state that SMEs are "a major engine" of economic growth and socioeconomic development (Henderson \& Weiler, 2010; Limaj \& Bernroider, 2019; Jamali, 2017; Soto-Acosta, 2016).

The situation is no different in the Czech Republic and Poland, which are considered to share similar levels of economic and social development (Siničáková et al., 2017), cultural and intellectual values, and common roots in diverse religious traditions. Still, while both countries have been analyzed from many perspectives, e.g., the GCI (Global Competitiveness Index) or innovativeness, as a rule, the Czech Republic has a higher position in such rankings than Poland (e.g., Ivanová \& Čepel, 2018).

One should state that creating and sustaining SMEs as part of worldwide - and especially local - community action supports the United Nations' 17 Sustainable Development Goals (SDGs) from ecological, social, and economic perspectives. Sustainable development is defined here as "a trajectory where future generations are assured the same level of welfare as present living generations." Of special relevance are Goal 8: "Decent Work and Economic Growth," Goal 9: "Industry, Innovation and Infrastructure" and Goal 12: "Responsible Consumption and Production" (UN, 2015). This strategy of being a sustainable business or, more precisely, being able to take part in the circular economy, is a challenge not only for policymakers but also mostly for individual entrepreneurs (Singh et al., 2018; Jansen, 2003; Lafferty, 2006; Nilsson 2016; Reyers et al., 2017).

Given these facts, the main goal of this paper is to compare methods of supporting effective waste management and the European Union's sustainable goals 8, 9, and 12 in both the Czech Republic and Poland. This assessment is to be the starting point for a deeper cross-border analysis. Thus, the following research question is posed: Do Czech and Polish SMEs have knowledge of "green" methods that could be used as internal indicators for achieving SDG 8, 9, and 12? The objectives of the study were achieved on the basis of data gathered through a Czech case study based on primary research and a Polish case study based on content analysis, i.e., data gathered on the basis of a literature review. The paper is structured as follows. Firstly, the analysis of the literature devoted to the sustainable development goals in SMEs is presented. This is followed by the methodological section, i.e., the materials and methods of the research that has been conducted. The next part of the paper analyses the results of the aforementioned research in 
detail (separately for both countries analyzed, i.e., the (zech Republic and Poland), and goes on to discuss the research results. Finally, the conclusions and limitations of our study are presented.

\section{LITERATURE REVIEW}

The economic monitoring burden in many countries is taken up by several agencies, and SDG management is not often centrally managed on a national level (Stafford-Smith et al., 2016). When a company sees that they will have to meet and overcome new challenges within the market in which they operate that is derived from government, legislation or public community action, business decisions can be described as being at the stage of "Business Sustainability 1.0". At this stage, they have mostly adopted the directives of SDG 8 within their business strategy (to save resources). In the next stage (named "Business Sustainability 2.0"), companies redefine their cooperation network, adding social and environmental values to their business model by adopting one more standard (SDG 9), which covers waste management. The business can then continue on the path to true business sustainability, meaning the minimization of negative impact and adopting a strategy that is proactive when it comes to environmental protection, reusing resources, and helping to develop the local community (as part of Business Sustainability 3.0, including the subsequent SDG 12 to close the sustainability strategy cycle).

This highest level of sustainability is also called the 'circular economy approach.' Geissdoerfer et al. (2017) define this as "a system in which resource input and waste, emission, and energy leakage are minimized by slowing, closing, and narrowing material and energy loops. This can be achieved through long-lasting design, maintenance, repair, reuse, remanufacturing, refurbishing, and recycling" (p.759). On the micro-level, sustainable development could be considered a linear process (Figure 1) in which primary resources are transformed into a final product, hence achieving welfare or utility; however, this activity brings about certain levels of waste which have to be reduced.

The research problem stated in our paper is not only to ascertain the proper "rules of the game" in the legal environment, but to be able to motivate entrepreneurs in the SME sector to support sustainable development goals (SDG 8, 9 and 12) and adapt these to their business, notwithstanding the fact that this was not their intention on start-up (Andersen, 2007) (Figure 1).

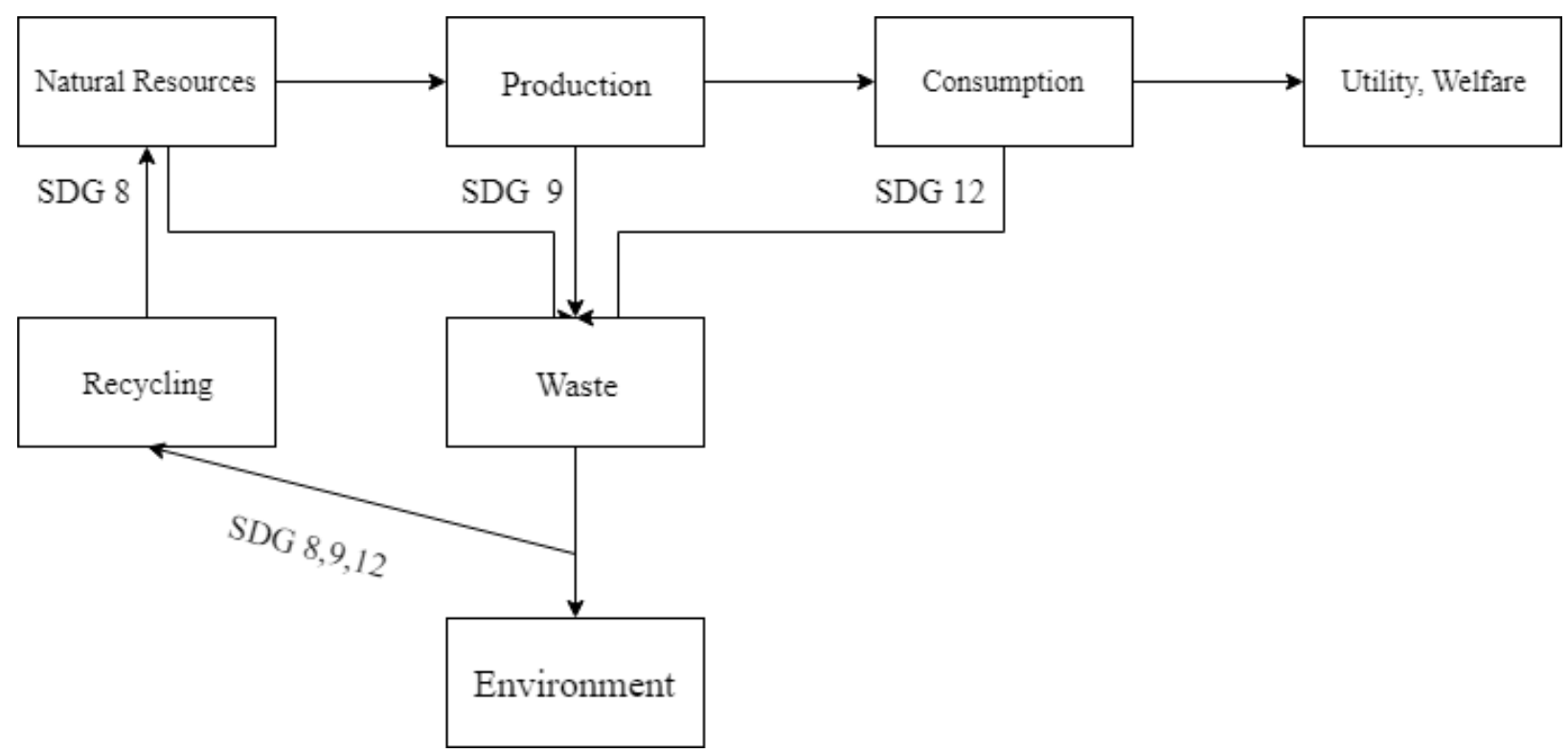

Figure 1. Sustainable process

Source: own elaboration based on Andersen, 2007 
Two countries, namely the Czech Republic and Poland, were chosen for comparison. A comparison will be made according to the classification by Geissdoerfer et al. (2017), as well as Dyllick and Muff (2015). A context analysis will be used in the Polish case, while results from primary data will be utilized in the case of Czechia. From a long-term perspective, both nations are below average in terms of ecoinnovation performance (Circular Economy and Eco-innovation, 2019)

This present reality is despite the fact that ecoinnovations are the key to Europe's future and are at the heart of the European Union's policies. The EU's economic prosperity and well-being are linked to its natural environment, and the global demand for renewable energy and resourceefficient solutions will be a source of new jobs and economic growth in the years to come (Zimmermanová et al., 2018). As numerous practical examples from industry demonstrate, eco-innovation is a powerful instrument that combines a reduced negative impact on the environment with a positive impact on the economy and society (Mikiashvili \& Lobzhanidze, 2017). Eco-innovation calls attention to the positive contribution that small and medium enterprises can make to sustainable development and to a competitive economy (Lesakova, 2019).

The Circular Economy and Eco-innovation (2019) report ranked the Czech Republic's ecoinnovation performance $18^{\text {th }}$ on the 2017 Ecoinnovation scoreboard out of 28 EU Member States, with an overall score of 97 , which is $3 \%$ below the overall EU average.

In contrast to Czechia, Poland has scored persistently poorly on the European EcoInnovation Scoreboard since 2010. In the 2017 edition, it was in 26th position among all the EU countries, with a score significantly below the EU average (59 out of 100).

One should also mention the use of a variety of incentives and a diversified set of instruments to better stimulate demand for eco-innovative products and services. In addition, cooperation with research centers and businesses, science and technology parks, as well as initiatives in the field of education and information are to be initiated and built upon, as eco-innovation development is a long-term process requiring the involvement of all stakeholders, as well as the adaptation of market participants to the ongoing socio-business changes (Urbaniec \& Gerstlberger, 2011; Valentine, 2010; Ferenc et al., 2017).

\section{DATA AND METHODS}

The primary quantitative instrument of research within the business population in the Czech Republic was the application of the stratified sample use method. The final response rate was $70 \%$ after a population of 300 potential respondents had been given the questionnaire. The working sample for the final case study evaluation, therefore, consisted of 210 entities and was a representative sample at a confidence level of $95 \%$ with a $5 \%$ margin of error (within the total business population in the Czech Republic by stratified sample size based on company size). The aim of the questionnaire survey was to identify the important factors that were barriers to green business activity. Data collection began in February 2017 and ran to April 2017 and was in the form of an electronic questionnaire.

All behavioral factors were evaluated on a Likert scale of 1 to 5 (where 1 - not connected with me and my business, 5 - I deal with that factor in my everyday life).

Of the respondents, $46 \%$ were involved in manufacturing activity, $27 \%$ were active in services, $21 \%$ in trade (wholesale and retail), and $6 \%$ in agriculture. The number of small businesses (enterprises employing up to 50 employees) that took part in the survey consisted of $58 \%$ of the entire sample, wherein enterprises employing up to 10 employees amounted to $20 \%$ and enterprises employing 11-49 employees consisted of $38 \%$ of the total. Medium-sized enterprises (between 50 and 250 employees) were represented in $30 \%$ of all cases, and large companies (250+ employees) constituted a $12 \%$ share of the entire response. More than $75.2 \%$ of all companies in the sample were in the growth phase, while $24.8 \%$ of the total had been in the crisis and decline phases within the last three years. Most companies had been operating on the market for more than ten years, and $41.4 \%$ were engaged in export activity. 


\section{RESEARCH RESULTS AND DISCUSSION}

\section{The case of the Czech Republic}

The analysis adopted in the study has four necessary steps. In the first step, a simple description was given to enable potentially important factors that affect current business behavior to be seen (Table 1). These results will have an influence on the next step - to find the motivation to use "green" methods for sustainability.

Table 1. Descriptive Statistics

\begin{tabular}{|l|c|c|}
\hline Variable & Mean & Std. Deviation \\
\hline Location & 3.3190 & 1.36887 \\
\hline Transport & 3.0762 & 1.28439 \\
\hline Workforce & 3.8762 & 1.24659 \\
\hline Legislation & 3.1000 & 1.36059 \\
\hline Bureaucracy & 2.8143 & 1.22134 \\
\hline Business Support & 2.1810 & 1.24340 \\
\hline Tradition & 2.3000 & 1.34502 \\
\hline Previous Activity & 1.7857 & 1.03839 \\
\hline Payment Behavior & 3.3429 & 1.46623 \\
\hline Alternative Financing & 2.1571 & 1.24088 \\
\hline Business Cycle & 1.5952 & 0.93470 \\
\hline
\end{tabular}

Source: own elaboration

To be able to support more connections to SDGs (specially to support sustainable behavior), the influence of the export and business cycle was chosen for cross-tabulation analysis in the next step. Accordingly, export activity could motivate entrepreneurs to behave more responsibly and link their goals to national priorities (Table 2 ).

Table 2. Influence of export activity on "green methods."

\begin{tabular}{|l|l|l|l|l|l|l|l|}
\hline \multicolumn{2}{|c|}{} & \multicolumn{5}{|c|}{ Methods } & \multirow{2}{*}{ Total } \\
\cline { 3 - 9 } \multicolumn{2}{|c|}{} & reuse & renovation & recycling & partial recycling & none & \\
\hline \multirow{2}{*}{ EXPORT } & no & $2.4 \%$ & $9.0 \%$ & $1.9 \%$ & $0.0 \%$ & $28.1 \%$ & $41.4 \%$ \\
\cline { 2 - 9 } & yes & $2.4 \%$ & $21.9 \%$ & $2.9 \%$ & $11.0 \%$ & $20.5 \%$ & $58.6 \%$ \\
\hline \multirow{2}{*}{ Total } & $4.8 \%$ & $31.0 \%$ & $4.8 \%$ & $11.0 \%$ & $48.6 \%$ & $100.0 \%$ \\
\hline
\end{tabular}

Source: own elaboration

While more than $58.6 \%$ of all respondents stated that they engage in export activity, the majority do not support any sort of wastereducing methods to meet SDGs. Still, the same group used renovation or participated in recycling processes; this connection was statistically important (Cramer's V $=0.390$, Sig. $0.000)$. On the other hand, their interest could relate to the current business cycle (Table 3 ). 
Table 3. Influence of the business cycle on "green methods."

\begin{tabular}{|c|c|c|c|c|c|c|c|}
\hline & \multicolumn{5}{|c|}{ Methods } & \multirow{2}{*}{ Total } \\
\hline & & reuse & renovation & recycling & partial recycling & none & \\
\hline \multirow{4}{*}{$\begin{array}{l}\text { BUSINESS } \\
\text { CYCLE }\end{array}$} & start-up & $1.90 \%$ & $19.52 \%$ & $2.38 \%$ & $8.10 \%$ & $33.81 \%$ & $65.71 \%$ \\
\hline & growth & $1.43 \%$ & $2.38 \%$ & $1.43 \%$ & $0.00 \%$ & $4.29 \%$ & $9.52 \%$ \\
\hline & maturity & $1.43 \%$ & $6.67 \%$ & $0.95 \%$ & $2.86 \%$ & $10.48 \%$ & $22.38 \%$ \\
\hline & decline & $0.00 \%$ & $2.38 \%$ & $0.00 \%$ & $0.00 \%$ & $0.00 \%$ & $2.38 \%$ \\
\hline \multicolumn{2}{|l|}{ Total } & $4.76 \%$ & $30.95 \%$ & $4.76 \%$ & $10.95 \%$ & $48.57 \%$ & $100.00 \%$ \\
\hline
\end{tabular}

Source: own elaboration

As illustrated in the table above, of the main alternative resource use and circular economy activity within start-ups, "renovation" occupies the leading position. This relationship was not confirmed as being statistically significant (Cramer's V = 0.176, sig. 0.052).

Finally, in order to derive sophisticated results, factor analysis was applied. All data obtained were tested for reliability, and the Kaiser-Meyer-
Olkin test (KMO) was above $0.6(\mathrm{KMO}=0.653$, df $=120$, sig. 0.00) when the IBM SPSS software package was applied. Factor rotation was evident when VARIMAX was used to obtain certain principal components when the dependent variable "green methods" was chosen. Seven factors were extracted in a total variance that was assessed at $67.27 \%$ (Table 4).

Table 4. Factor analysis

\begin{tabular}{|l|c|c|c|c|c|c|c|}
\hline \multicolumn{7}{|c|}{ Rotated Component Matrix } \\
\hline \multicolumn{1}{|c|}{ Variables } & \multicolumn{7}{c|}{ Component } \\
\cline { 2 - 9 } & F1 & F2 & F3 & F4 & F5 & F6 & F7 \\
\hline Bureaucracy & .846 & & & & & & \\
\hline Alternative Financing & .794 & & & & & & \\
\hline Legislation & .662 & & & & & & \\
\hline Business cycle & & .672 & & & & & \\
\hline Previous Activity & & .659 & & & & & \\
\hline Transportation & & & .774 & & & & \\
\hline Locality & & & .773 & & & & \\
\hline Export & & & & .818 & & & \\
\hline NACE branch & & & & -.630 & & & \\
\hline Size & & & & & .773 & & \\
\hline Age & & & & & & .833 & \\
\hline Workforce & & & & & .708 & \\
\hline Payment Behavior & & & & & & & .816 \\
\hline Business Support & & & & & .820 & & \\
\hline
\end{tabular}

Source: own elaboration

As shown in the table, the main group of factors that affect a business are political factors, including legislation and bureaucracy (F1), followed by the stage of business examined (F2) and logistics issues such as location or transportation (F3). The analysis confirmed the 
negative influence of the NACE branch on export activities (F4). Also, dependence on workforce and business support is observed (United Nation goals SDG 8 and 12). To sum up, small businesses are moving slowly towards implementing the circular economy because they are motivated to do so, mostly either at the start of their operations or by their exporting activity. If we use the classification of Dyllick and Muff (2015), the examined businesses are on level 1.0 of business sustainability. They start by redefining value, and by observing changes.

A motivational factor could be seen in the status of "product exporting" - the respondents are more motivated to change their habits to behave sustainably (according to SDG standards) because it is what their customers want. This observation expands on the findings of Zimmermannová et al. (2018), when the study focused on the entrepreneurial segment, and not only on public support. Unfortunately, the study did not deal with innovative activities as being sources of sustainability, as did Ivanova and Čepel (2018). However, the results achieved do not support the previous work of Šebestová et al. (2017), where the respondents did not identify their main export partners (Table 2) to make it possible to confirm cross-border cooperation in Visegrad Four countries.

\section{The case of Poland}

To illustrate the significance and main areas of research in Poland in this topic, the examples of studies chosen randomly in the last three years were utilized. We compared the type of study, research area, and methods. Some of these papers (in fact the majority) were published only in the Polish language and were theoretically oriented, thus mirroring the evaluation derived from the European Eco-Innovation Scoreboard, which was very low. However, there are also studies that are based on qualitative research undertaken within small companies operating in different sectors and/or locations (Table 5).

Table 5. Examples of SDG studies

\begin{tabular}{|c|c|c|c|}
\hline Author & Area of business & Type of research & Methods used/explained \\
\hline $\begin{array}{l}\text { Kachniewska, } \\
2018\end{array}$ & Hospitality & $\begin{array}{l}\text { Qualitative, } 56 \\
\text { interviews }\end{array}$ & $\begin{array}{l}\text { Waste prevention, preparing for re-use, } \\
\text { recycling, other recovery processes, } \\
\text { disposal. }\end{array}$ \\
\hline $\begin{array}{l}\text { Kuczyńska- } \\
\text { Chałada, } 2015\end{array}$ & $\begin{array}{l}\text { Steel production, } \\
\text { metallurgy }\end{array}$ & $\begin{array}{l}\text { Secondary data, } \\
\text { context research }\end{array}$ & $\begin{array}{l}\text { Use of waste-free or low-waste } \\
\text { technologies, the use of recycling, } \\
\text { reducing material consumption and } \\
\text { energy consumption in production }\end{array}$ \\
\hline $\begin{array}{l}\text { Lewandowski, } \\
2016\end{array}$ & - & $\begin{array}{l}\text { Literature } \\
\text { review, lack of } \\
\text { empirical } \\
\text { evidence }\end{array}$ & $\begin{array}{l}\text { Circular business model canvas, triple fit } \\
\text { challenge }\end{array}$ \\
\hline $\begin{array}{l}\text { Patorska and } \\
\text { Karbowska, } 2016\end{array}$ & - & $\begin{array}{l}\text { Secondary data, } \\
\text { statistics on } \\
\text { waste }\end{array}$ & Zero-waste, recycling policy \\
\hline Chyłek, 2016 & Agriculture & $\begin{array}{l}\text { Secondary data, } \\
\text { policy review }\end{array}$ & $\begin{array}{l}\text { Eco-innovations, bio-economy, smart } \\
\text { manufacturing }\end{array}$ \\
\hline $\begin{array}{l}\text { Jaworski, } \\
\text { Grochowska, } 2017\end{array}$ & - & $\begin{array}{l}\text { Secondary data, } \\
\text { policy review }\end{array}$ & $\begin{array}{l}\text { Evaluation of EU policy implementation } \\
\text { in waste management }\end{array}$ \\
\hline $\begin{array}{l}\text { Ociepa-Kubicka } \\
\text { and Pachura, } 2017\end{array}$ & $\begin{array}{l}\text { Water and sewage } \\
\text { enterprises }\end{array}$ & $\begin{array}{l}\text { Literature } \\
\text { review }\end{array}$ & Eco-innovations in companies \\
\hline $\begin{array}{l}\text { Malik and } \\
\text { Jasińska-Biliczak, } \\
2018 \\
\end{array}$ & $\begin{array}{l}\text { Companies } \\
\text { located in Opole } \\
\text { province }\end{array}$ & $\begin{array}{l}\text { Qualitative, } 150 \\
\text { questionnaires }\end{array}$ & $\begin{array}{l}\text { Innovations facilitating sustainable } \\
\text { development }\end{array}$ \\
\hline
\end{tabular}

Source: own elaboration 
As one may see from Table 5, most studies are oriented towards policy review. There are also analyses concentrating on practical studies (Kachniewska, 2018; Malik \& Jasińska-Biliczak, 2018). The latter authors, based on an analysis of SMEs located in Opole province, state that there are misunderstandings in the way SMEs in emerging economies use and understand the concept of sustainable development. Their research showed that SMEs in this emerging economy equate sustainable development with quality management systems, integrated quality, and environmental management systems, or simply regarded any development as sustainable. In general, one may state that all the published studies are closely connected with the level of development of this area in Poland. According to Dyllick and Muff (2015), one can be sure that the examined study has shown that businesses are below level 1.0 of business sustainability.

Table 6. SDG goals and their achievements

\begin{tabular}{|c|c|c|c|c|}
\hline & \multicolumn{2}{|c|}{ Czech Republic } & \multicolumn{2}{c|}{ Poland } \\
\hline $\begin{array}{r}\text { Level of goal } \\
\text { implementation }\end{array}$ & $\begin{array}{c}\text { Microlevel } \\
\text { (Entrepreneurs, } \\
\text { SMEs) }\end{array}$ & $\begin{array}{c}\text { Macrolevel } \\
\text { (Policy level) }\end{array}$ & $\begin{array}{c}\text { Microlevel } \\
\text { (Entrepreneurs, } \\
\text { SMEs) }\end{array}$ & $\begin{array}{r}\text { Macrolevel } \\
\text { (Policy level) }\end{array}$ \\
\hline SDG 8 & $\sqrt{ }$ & $\sqrt{ }$ & $\sqrt{ }$ & $\sqrt{ }$ \\
\hline SDG 9 & - & $\sqrt{ }$ & $\mathrm{x}$ & $\mathrm{x}$ \\
\hline SDG 12 & - & - & & \\
\hline
\end{tabular}

Source: own elaboration

In qualitative terms, in Table 6 , the tick $(\sqrt{ })$ means that the country/enterprises fulfill the criterion. In contrast, the cross $(\mathrm{X})$ indicates that the country/enterprises fail the criterion, and space (-) means that there is uncertainty as to whether the country/enterprises fulfill or fail to meet the criterion. Analysis of Table 6 allows us to state that Czech society and Czech entrepreneurs have more knowledge of and practice in "green" methods than their Polish counterparts.

When comparing both countries, the Czech Republic has a certain advantage in evaluation. Patorska and Karbowska (2016) deem this country to exemplify a higher level in ecoinnovation, wherein waste management or a centralized approach to "green" policy falls under the auspices of the Ministry of Environment of the Czech Republic. It must be reiterated that the successful achievement of SDGs 8, 9, and 12 are connected with clear regulation and public support.

This comparison expanded the study of Urbaniec (2014), who counted the dynamics of ISO 14001 certificates and EMAS registrations within the Visegrad Four countries. Here, the position of the Czech Republic was slightly more positive than that of Poland.

\section{CONCLUSIONS}

The research has confirmed that there are differences in both countries in relation to sustainable development goals and SME decisions. One of the reasons for this difference is that in need to achieve sustainable goals, SMEs are motivated by the customers' requirements to obtain appropriate certificates, and in how they actually deal with ecological goals. In addition, Czech society and Czech entrepreneurs have more knowledge of and practice in applying "green" methods than their Polish counterparts.

This study contributes to the prior literature in several ways. First, this research adopts an international approach, analyzing SMEs operating in two Central European countries. The countries differ in terms of size and number of SMEs; moreover, they are neighboring economies with similar heritage and values. This offers us a wider perspective than would be the case in a single-country approach, allowing us to potentially obtain more generalizable results. Second, given the growing role of sustainable 
development in any aspect of a business, as well as non-business activities, one should expect that the content of study programs related to sustainable development will have to take this growing trend into account.

This study has several limitations. First of all, it adopts a combination of two types of comparisons, i.e. based on desk research and primary data research (in the case of Poland, empirical evidence is conditioned on the availability of information based only on the review of the literature). Secondly, the main point was to declare a starting point of the business sustainability level in each country with regard to SDG 8, 9 and 12. Thirdly, the number of countries analyzed (two) may also be regarded as a limitation. Research conducted on a greater scale would provide more valuable data and information.

There is a need for further research on the presented topic. It seems that some form of cyclical research, for example conducted every three to five years, would allow researchers to obtain more valid data and allow them to provide some indications as to the direction in which the sustainable development goals of SMEs will evolve. Despite the limitations presented, one can state that the results achieved allowed to obtain a true picture of the situation in the SME sector in the Czech Republic and Poland.

\section{ACKNOWLEDGEMENT}

This work was supported by the Silesian University in Opava, by the Student Grant System SGS/06/2018 "Economic Literacy of Business Entities".

The project was funded within the auspices of the programme of the Minister of Science and Higher Education entitled "Regional Initiative of Excellence" in 2019-2022, project number $018 /$ RID/2018/19, the amount of funding PLN $10,788,423.16$.

\section{REFERENCES}

Andersen, M. S. (2007). An introductory note on the environmental economics of the circular economy, Sustainability Science, 2(1), 133140. DOI: $10.1007 / \mathrm{s} 11625-006-0013-6$
Androniceanu, A. (2019). Social responsibility, an essential strategic option for sustainable development in the field of bioeconomy, Amfiteatru Economic, 21(52), 347-364.

Androniceanu, A., Gherghina, R., Ciobanasu, M. (2019). The interdependence between public fiscal policies and tax evasion, Administratie si Management Public, (32): 32-41, DOI: 10.24818/amp/2019.32-03.

Bădulescu, D. (2010), SMEs financing: the extent of need and the responses of different credit structures, Theoretical \& Applied Economics, 17(7), 25-36.

Borocki, J., Radišić, M., Sroka, W., Greblikaite, J., Androniceanu, A. (2019). Methodology for strategic posture determination of SMEs, Inzinerine Ekonomika - Engineering Economics, 30(3), 265-277. DOI: 10.5755/j01.ee.30.3.21966

Circular Economy and Eco-Innovation: Poland (2019). Retrieved August 20, 2019, from https://ec.europa.eu/environment/ecoap/pol and_en.

Dyllick, T., Muff. K. (2016). Clarifying the meaning of sustainable business: Introducing a typology from business-asusual to true business sustainability, Organization \& Environment, 29(2), 156174. DOI: $10.1177 / 1086026615575176$

Chyłek, E. K. (2016). Nowe strategie Komisji Europejskiej dotyczące biogospodarki i gospodarki wewnętrznej o obiegu zamkniętym, Polish Journal of Agronomy, 25, 3-12 (Original work written in Polish).

European Commission (2005). The new SME definition: User guide and model declaration, Enterprise, and Industry Publications.

Ferenc, P., Varmus, M., Vodák. J. (2017). Stakeholders in the various field and relations between them, Procedia Engineering, 192, 166-170. DOI: 10.1016/j.proeng.2017.06.029

Geissdoerfer, M., Savaget, P., Bocken, N.M.P., Hultink, E.J. (2017). The circular economy a new sustainability paradigm? Journal of Cleaner Production, 143, 757-768. DOI: 10.1016/j.jclepro.2016.12.048 
Groucutt, Ch., Vochozka, M., Kral, P., Sroka, W. (2018). The \#metoo social media campaign, sexualized forms of male control, and the failure of current law to curb gendered harassment and misconduct in the workplace, Contemporary Readings in Law and Social Justice, 10(2), 86-92. DOI:10.22381/CRLSJ10220188

Henderson, J., Weiler, S. (2010). Entrepreneurs and job growth: Probing the boundaries of time and space, Economic Development Quarterly, 24, 23-32. DOI: $10.1177 / 0891242409350917$

Ivanová, E., Čepel, M. (2018). The impact of innovation performance on the competitiveness of the Visegrad 4 countries, Journal of Competitiveness, 10(1), 54-72. https://doi.org/10.7441/joc.2018.01.04.

Jamali, D., Lund-Thomsen, P., Jeppesen, S. (2017). SMEs and CSR in developing countries, Business \& Society, 56(1), 11-22. DOI: $10.1177 / 0007650315571258$

Jansen, L. (2003), The challenge of sustainable development, Journal of Cleaner Production, 11(3), 231-245.

Jaworski, T. J., Grochowska, S. (2017). Circular Economy - the criteria for achieving and the prospect of implementation in Poland, Archives of Waste Management and Environmental Protection, 19(4), 13-22.

Kachniewska, M. (2018). Circular economy in the opinions of small- and medium-sized hotel enterprises, Folia Turistica, 48, 185208.

Karpak, B., Topcu, I. (2010). Small medium manufacturing enterprises in Turkey: An analytic network process framework for prioritizing factors affecting success, International Journal of Production Economics, 125(1): 60-70. https://doi.org/10.1016/j.ijpe.2010.01.001.

Kozma, T. (2017). Cooperation in the supply chain network, Forum Scientiae Oeconomia, 5(3), 45-58. https://doi.org/ 10.23762/FSO_vol5no3_17_3.

Kuczyńska-Chałada M. (2015). Logistyka powtórnego zagospodarowania odpadów i możliwości jej zastosowania w przedsiębiorstwach hutniczych, in: $R$. Knosala (Ed.) Innowacje w zarządzaniu i inżynierii produkcji (pp. 890-899), Opole:

Oficyna Wydawnicza Polskiego

Towarzystwa Zarządzania Produkcją

(Original work written in Polish).

Lafferty, W. M. (2006). Governance for sustainable development: The challenge of adapting form to function, Cheltenham: Edward Elgar Publishing.

Lendel, V., Varmus. M. (2013). Use of innovation in marketing management of Slovak business enterprises, Verslas: teorija ir praktika = Business: Theory and Practice, 14(1), 35-42. DOI: 10.3846/btp.2013.04

Lesakova, L. (2019). Small and medium enterprises and eco-innovations: empirical study of Slovak SME's, Marketing and Management of Innovations, 3, 89-97. http://doi.org/10.21272/mmi.2019.3-07

Lewandowski, M. (2016). Designing the business models for circular economy-towards the conceptual framework, Sustainability 2016, 8, 43; doi:10.3390/su8010043

Limaj, E., Bernroider, E. W. N. (2019). The roles of absorptive capacity and cultural balance for exploratory and exploitative innovation in SMEs, Journal of Business Research, 94, 137-153.

Malik, K., Jasińska-Biliczak, A. (2018). Innovations and other processes as identifiers of contemporary trends in the sustainable development of SMEs: The case of emerging regional economies, Sustainability 2018, 10, 1361; doi:10.3390/su10051361

Massaro, M., Rubens, A., Bardy, R., Bagnoli, C. (2017). Antecedents to export performance and how Italian and Slovenian SME's Innovate during times of crisis, Journal of Eastern European and Central Asian Research,4(1), 1-22. DOI: $10.15549 /$ jeecar.v4i1.153

Mikiashvili, N., Lobzhanidze, N., (2017). Green innovations and economic policy in small economies, Forum Scientiae Oeconomia, 5(2), 29-40. DOI: 10.23762/fso_vol5no2_17_3

Meyer, N., De Jongh, J.J. (2018). The importance of entrepreneurship as a contributing factor to economic growth and development: The case of selected European countries, Journal 
of Economics and Behavioral Studies, 10(4): 287-299. DOI: $10.22610 /$ jebs.v10i4.2428

Moravcikova, D., Kliestikova, J. (2017). Brand building with using phygital marketing communication, Journal of Economics, Business and Management, 5(3), 148 -153. DOI: $10.18178 /$ joebm.2017.5.3.503

Nilsson, M., Griggs, D., Visbeck, M. (2016), Policy: Map the interactions between Sustainable Development Goals, Nature, 534, 320-322. DOI: 10.1038/534320a

Ociepa-Kubicka, A., Pachura, P. (2017). Ecoinnovations in the functioning of companies, Environmental Research, 156, 284-290. https://doi.org/10.1016/j.envres.2017.02.02 7

OECD (2010), Eco-innovation in industry: enabling green growth, OECD Publishing, Paris.

Olah, J., Virglerova, Z., Popp, J., Kliestikova, J., Kovács, S. (2019). The assessment of nonfinancial risk sources of SMES in the V4 countries and Serbia, Sustainability 2019, 11, 4806; doi:10.3390/su11174806

Patorska, J., Karbowska, D. (2016). Rozszerzona odpowiedzialność producenta a pakiet Komisji Europejskiej dotyczący gospodarki o obiegu zamkniętym, Logistyka Odzysku, 2(19), 38-44 (Original work written in Polish).

Reyers, B., Stafford-Smith, M., Erb, K.-H., Scholes, R.J., Selomane, O. (2017). Essential variables help to focus sustainable development goals monitoring, Current Opinion in Environmental Sustainability, 26-27, 97105. DOI: $10.1016 /$ j.cosust.2017.05.003

Sebestova, J., Sperka, R., Malecka, J., Luczka, T. (2017). Co-working centres as a supportive network for cross border business cooperation, Forum Scientiae Oeconomia, 5(4), 23-34. DOI: 10.23762/FSO_VOL5NO4_17_2.

Singh, G. G., et al. (2018). A rapid assessment of co-benefits and trade-offs among Sustainable Development Goals, Marine Policy, 93, 223-231. https://doi.org/10.1016/j.marpol.2017.05.03 0
Siekelova, A., Kovacova, M., Adamko, P., Stehel, V. (2019. Profit management as an instrument for SMEs developing: the case for Slovakia, Marketing and Management of Innovations, 3, 285-296. http://doi.org/10.21272/mmi.2019.3-22

Siničáková, M., Sulikova, V., Gavurova, B. (2017). Twin deficits threat in the European Union, E+M Economics and Management, 20(1), 144-156. https://doi.org/10.15240/tul/001/2017-1010.

Soto-Acosta, P., Popa, S., Palacios-Marques, D. (2016), E-business, organizational innovation and firm performance in manufacturing SMEs: an empirical study in Spain, Technological and Economic Development of Economy, 22(6), 885-904.

Sroka, W., Szanto, R. (2018), CSR and business ethics in controversial sectors: analysis of research results, Journal of Entrepreneurship, Management and Innovation, 14(3), 111-126. https://doi.org/10.7341/20181435

Sroka, W., Vveinhardt, J. (2018). Nepotism and favouritism in the steel industry: A case study analysis, Forum Scientiae Oeconomia, 6(1), 31-45. DOI: 10.23762/FSO_VOL6NO1_18_4.

Stafford-Smith, M., Griggs, D., Gaffney, O., Ullah, F., Reyers, B., Kanie, N., Stigson, N., Shrivastava, P., Leach, M., O'Connell, D. (2017). Integration: the key to implementing the Sustainable Development Goals, Sustainability Science, 12(6), 911919. https://doi.org/10.1007/s11625-0160383-3

UN (2015). Transforming our world: the 2030 Agenda for Sustainable Development. Retrieved August 15, 2019 from https://sustainabledevelopment.un.org/post 2015/ transformingourworld/publication.

Urbaniec, M. (2014). Implementation of international standards for environmental management in Visegrad countries: a comparative analysis, Entrepreneurial Business and Economics Review, 2(2), 6576.

Urbaniec, M., Gerstlberger, W. (2011). Innovation in environment-oriented 
networks: Influence factors from case study and survey research, Management of Environmental Quality: An International Journal, 22(6), 686-704. DOI: $10.1108 / 14777831111170812$

Valentine, S.V. (2010). The green onion: A corporate environmental strategy framework, Corporate Social Responsibility and Environmental Management, 17(5), 284-298. https://doi.org/10.1002/csr.217

Velinov, E., Ponomarev, M. (2016). Organizational development of Russian SMEs: Current trends, Journal of Eastern European and Central Asian Research, 3(2), 1-10. DOI: 10.15549/jeecar.v3i2.142

Zimmermanová, J., Pawliczek, A., Čermák, P. (2018). Public support of solar electricity and its impact on households - prosumers, Organizacija, 51(1), 4-19. DOI: 10.2478/orga-2018-0001

\section{ABOUT THE AUTHORS}

Włodzimierz Sroka, email: wsroka@wsb.edu.pl

Dr. Jarmila Šebestová, is an associate professor at Silesian University in Opava, School of Business Administration in Karvina, Czech Republic. She is an experienced researcher focusing on Small Businesses. She has participated in a number of international projects, including IPREG (Innovative Policy Research for Economic Growth) and the EWORLD project (International Entrepreneurs Network). She is Vice President of the European Council of Small Businesses for the Czech Republic. Her research interests include small business performance and small business dynamics

Dr. Włodzimierz Sroka, Ph.D., is an associate professor in the Management Department of WSB University in Dąbrowa Górnicza, Poland \& North West University, South Africa. He specializes in theoretical and practical issues relating to management and strategic management. He is the author of numerous scientific papers about strategic alliances, network organizations, strategy, company restructuring, CSR and business ethics, as well as innovations and entrepreneurship. His research activities mostly include cooperative strategies (e.g., alliances, network organizations), co-operative relations, M\&A, business ethics and CSR, innovations, and entrepreneurship. He merges his scientific activity with being the CEO of a medium-sized engineering company. He was previously employed in different managerial positions in both the steel and machine industries. ORCID no. http://orcid.org/0000-0002-8701-0716. 